\title{
Matthew and marginality
}

\section{Dennis C Duling \\ Canisius College, Buffalo (NY)}

\begin{abstract}
This article explores marginality theory as it was first proposed in the social sciences, that is related to persons caught between two competing cultures (Park; Stonequist), and, then, as it was developed in sociology as related to the poor (Germani) and in anthropology as it was related to involuntary marginality and voluntary marginality (Victor Turner). It then examines a 'normative scheme' in antiquity that creates involuntary marginality at the macrosocial level, namely, Lenski's social stratification model in an agrarian society, and indicates how Matthean language might fit with a sample inventory of socio-religious roles. Next, it examines some 'normative schemes' in antiquity for voluntary marginality at the microsocial level, namely, groups, and examines how the Matthean gospel would fit based on indications of factions and leaders. The article shows that the author of the Gospel of Matthew has an ideology of 'voluntary marginality', but his gospel includes some hope for 'involuntary marginals' in the real world, though it is somewhat tempered. It also suggests that the writer of the Gospel is a 'marginal man', especially in the sense defined by the early theorists (Park; Stonequist).
\end{abstract}

\section{INTRODUCTION}

There is an increasing tendency in New Testament study to refer to Jesus, Jesus movements, gospel characters, and other Christian persons and groups as 'marginal' (Schüssler Fiorenza 1983:141; Kloppenborg 1986:36-56; Karris 1990; Meier 1991). This tendency has also found its way into study of the Gospel of Matthew. Anderson (1983:10-17) has forcefully argued that the woman with the hemorrhage (Mt 9:20-22) and the Canaanite woman (Mt 15:21-28) are not only marginal because they come from marginal groups, the ritually unclean and Gentiles, but also because they are women: they are 'doubly marginal'1. From the perspective of redaction criticism, Donahue (1986) contends that the 'parable' of the sheep and the goats in Matthew 25 is the hermeneutical key to the gospel. To be sure, says Donahue, acts of mercy toward the 'least of my brothers and sisters' in this parable refer to acts toward the Matthean 
apostles/missionaries; nonetheless, 'the criterion of judgment will be works of charity and mercy shown toward the marginal, the poor and the suffering of the world' (Donahue 1986:3; 1988:125; Van Aarde 1994:83-86, 147). Several recent social historians have viewed the Matthean community as sectarian (see e g Overman 1990; Balch 1991), and if one were to argue that 'sects' are marginal groups, the conclusion would be that the community as a whole is marginal. Finally, from the perspective of deviance and labeling theory in the social sciences, Malina \& Neyrey's (1988) work might be seen as a contribution to the analysis of Matthew from the perspective of marginality.

In this article, I have two aims. First, I explore the conceptuality of marginality as it has emerged among certain social scientists. Second, I try to show from this perspective in what sense the author of Matthew is concerned about marginal people and in what sense he might be considered a marginal figure himself. First, then, some social scientific discussion about marginality.

\section{MARGINALITY THEORY}

\section{1 'Marginal Man'}

Robert E Park, leader of the Park School of sociology of the University of Chicago, first used marginality as a distinct theoretical concept to describe ethnic immigrants to the United States in relation to the dominant Anglo-Saxon majority (Park 1928:881893; 1931:95-110; see also Schermerhorn 1964:406-407). Park referred to 'marginal man', that is, a person who is condemned to live in two different, antagonistic cultural worlds, but does not fully belong to either. Such persons are not fully acculturated. The 'marginal man' or 'marginal woman' can also be the child of marriages from two different cultural representatives.

Stonequist (1937) elaborated Park's insight in a fascinating and influential social psychological work titled The marginal man. For Stonequist, 'the marginal personality is most clearly portrayed in those individuals who are unwittingly initiated into two or more historic traditions, languages, political loyalties, moral codes, or religions' (Stonequist 1937:3). Stonequist organized his study around two types of marginals: racial mixtures (e g, Eurasians of India; Cape Colored of South Africa; Mulattoes of the United States) and cultural mixtures, which were further subdivided into migrant foreigners (Europeanized Africans; Westernized Orientals), second generation American immigrants, American Negroes, and Jews emancipated from the ghetto. Stonequist also mentioned the parvenu, the upwardly mobile marginal, often satirized (e g, the ancient Trimalchio) or praised (e g, the modern Horatio Alger), and the opposite, the 
déclassé, or downwardly mobile marginal. Noted as well were the migrant from the farm to the city and women who find themselves in a new social role previously occupied only by men (see Stonequist 1937:5-6).

In subsequent studies American sociologists discussed marginality in connection with high crime rate, family dysfunction, and emotional distress among immigrants. They eventually turned to other types of social contact, mostly subcultures within a larger culture. There was continued study of movements up and down various levels of the social ladder, ethnic subcultures in relation to the dominant culture, and urbanization and detribalization in Africa - in short, anything that produces 'status incongruence' (Schermerhorn 1964:407).

In line with such developments, a computer search of the word 'marginality' today will turn up hundreds of titles that range from studies of the pcor, particularly in Latin America, to migrant workers in Germany, French avant-garde literary figures, the handicapped, and women in higher education. For my purposes, it will be important to explore two more theoretical areas, or what I shall call involuntary marginality and voluntary marginality.

\subsection{Involuntary marginality}

Germani (1980) has written a useful work on theoretical sociology titled simply Marginality. He states that at the descriptive level, one can observe certain phenomena typical of urban ecological environments: segregated shantytowns, squatter settlements, poor working conditions, low standard of living, and the exclusion of such groups from the decision making process that affects their lives. Germani thinks that similar phenomena can exist in rural areas. These phenomena represent subcultures, sometimes ethnic populations, with differing norms, values, and attitudes than those held by the majority culture; such persons are dominated by economic, political, and cultural elites. They are not in 'the center' (usually modern and developed), but are on 'the periphery' (usually underdeveloped and archaic). When they exist side by side in a single political entity, such as a national state, these phenomena point to a kind of internal colonialism, a society within a society. Germani argues that such groups and persons are roughly equivalent to those who live in poverty and that they have some level, however minimal, of social participation; therefore, they do not represent a totally separate class unrelated to the rest of the social structure, as some analysts have affirmed.

At the explanatory level, Germani offers five basic, interrelated causal factors for these phenomena: economic and social (especially unemployment); political (limitation of participation on the basis of class, race, sex, ethnicity); demographic (overpopula- 
tion); cultural (domination of one cultural group by another; [neo]colonialism; ruralurban contrasts); and psychosocial (powerlessness; helplessness; status inferiority; inadequate early socialization). After considering the origins of the concept of marginality, and arguing for some similarity between developed and developingcountries (despite the ubiquity of the phenomenon in developing countries), Germani observes certain correlations with social stratification. While there is some validity in correlating marginals with the bottom of the social hierarchy, it is also possible to think of marginals at each level of the social hierarchy in terms of a participant/nonparticipant continuum. On this basis, Germani arrives at a generalized definition of marginality:

... we may define marginality as the lack of participation [exercise of roles] of individuals and groups in those spheres in which, according to determined criteria, they might be expected to participate.

(Germani 1980:49)

The 'lack of participation' in this definition means the inability of persons to conform to expected social roles with respect to sex, age, civil life, occupation, and social life in relation to levels of status in the social system. These statuses are based on social norms, values, and expectations rooted in law and legitimated by custom. In other words, the marginal person no longer participates in what Germani calls 'the normative scheme', that is:

the set of values and norms which define the categories (status), the legitimate, expected, or tolerated areas of participation and the assignment mechanisms of individuals to each category.

(Germani 1980:51)

Lack of participation often occurs because of a new and competing 'normative scheme'2. For marginal persons there are two related elements. First, the usual 'objective resources', both material and nonmaterial - education, jobs, purchasing power, housing - are not available. Second, the 'personal conditions' needed to exercise their social roles are not present. 
We refer here to psychological features on the emotional, volitive and intellectual level as well as the cognitive patrimony: attitudes propensities, motivations, behavior patterns or more generally type of personality, intellectual capacity and general and technical knowledge.

(Germani 1980:51)

I refer to this type of marginality with the shorthand expression involuntary marginality.

The above analysis leads Germani (1980:54) to a methodological approach for studying marginality:

$\ldots$ in whatever analysis, the interpretation of the data and situations, the empirical research and the diagnosis of marginality must be made explicit with regards to the normative scheme, and marginality criteria and the explanatory system utilized.

(Germani 1980:54)

Much of Germani's analysis focuses on 'modernization' in relation to the Third World, that is, Enlightenment conceptions of political freedom, economic development, secure employment, and industrialization. This orientation is too Western and modern for direct application to Greco-Roman antiquity. Yet, Germani's general analysis is abstract enough to engage almost any social system. Thus, in analyzing Matthew and marginality one ought to develop the 'normative scheme' in the social context of the Gospel of Matthew, and to indicate, if possible, how and to what extent the author of Matthew and/or his group are marginal with respect to marginality criteria.

\subsection{Voluntary marginality}

The anthropologist Victor Turner $(1969,1974)$ takes quite a different approach to marginality. It is part of the analysis of ritual. Building on van Gennep's (1960) classic analysis of rites of passage, Turner (1969:94-95) sees a common pattern in ritual:

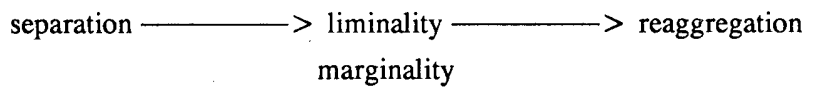


'Separation' removes individuals or groups, usually secluded physically, from their accepted statuses or roles in a social system marked by law, custom, convention, and ceremonial - the center - to the margin. In this transitional, 'liminal' phase (Latin limen: 'threshold') individuals or groups are in limbo. They are 'neither here nor there'; they are 'betwixt and between' (Turner 1969:95). In the third phase, the initiate re-enters the social system as a neophyte, often with higher status. Turner characterizes the second, or marginal, liminal phase by communitas, a status-less, role-less phase marked by spontaneity, concreteness, intense comradeship, and egalitarianism. Those in this phase are often considered sexless and anonymous, sometimes symboled by nakedness.

Turner (1969:126) also views this model in terms of structure/anti-structure: 'For me, communitas emerges where social structure is not'. Structure refers to a '... differentiated, and often hierarchical system of politico-legal-economic positions with many types of evaluation, separating men in terms of 'more' or 'less' (Turner 1969:131). In structure, there are fixed 'relationships between statuses, roles, and offices' (Turner 1969:131). Contrariwise, anti-structure is 'spontaneous, immediate, concrete'; 'individuals are not segmentalized into roles and satuses but [existentially] confront one another ...' (Turner 1969:127, 132).

The specifics of Germani's analysis are too modern for Greco-Roman society. Likewise, the specifics of Turner's analysis are drawn too much from small tribal societies, notably the Ndembu. Yet, as Germani generalizes, so does Turner:

\begin{abstract}
The time has now come to make a careful review of a hypothesis that seeks to account for the attributes of such seemingly diverse phenomena as neophytes in the liminal phase of ritual, subjugated autochthonous, small nations, court jesters, holy mendicants, good Samaritans, millenarian movements, 'dharma bums,' matrilineal systems and monastic orders. Surely an ill-assorted bunch of social phenomena! Yet all have this common characteristic: they are persons or principles that (1) fall in the interstices of social structure, (2) are on its margins, or (3) occupy its lowest rungs.
\end{abstract}

(Turner 1969:125)

Turner (1969:132) goes further and develops another general principle: 'the spontaneity and immediacy of communitas ... can seldom be maintained for very long. Communitas itself soon develops a structure ...' From this insight Turner distinguishes three kinds of communitas: 
(1) existential or spontaneous communitas - approximately what the hippies today [sic!] would call 'a happening,' and William Blake might have called 'the winged moment as it flies', or, later, 'mutual forgiveness of each vice'; (2) normative communitas, where, under the influence of time, the need to mobilize and organize resources, and the necessity for social control among the members of the group in pursuance of these goals, the existential communitas is organized into a perduring social system; and (3) ideólogical communitas, which is a label one can apply to a variety of utopizin models of societies based on existential communitas.

(Turner 1969:132)

Whereas spontaneous communitas stands apart from social structures, normative communitas represents an emergent microsocial group within a macrosocial system ${ }^{3}$. Finally, ideological communitas presents communitas as desired vision, or what is known in Christian history as the ecclesiola in ecclesia. As examples, Turner analyzes the early Franciscans of medieval Europe and the Sahajiyas of fifteenth- and sixteenthcentury India.

For Turner (1974:123) normative communitas is on the way to stricture, and ideological communitas is voluntary 'outsiderhood'. It is not socially imposed marginality, but voluntarily chosen marginality (Turner 1974:266). That he is not developing the concept of involuntary marginality is clear from his statement about poverty:

Liminal poverty must not be confused with real poverty, although the liminally poor may become actually poor. But liminal poverty, whether it is a process or a state, is both an expression and instrumentality of communitas. Communitas is what people really seek by voluntary poverty .... The principle is simple: cease to have and you are; if you 'are' in the relationship of communitas to others who 'are,' then you love one another.

(Tuiner 1974:266)

\subsection{Marginality summary}

The concept 'marginality' in the social science literature examined above has three dimensions: 
* the Marginal Man: individuals and groups who, because of birth, migration, conquest, and the like are 'doomed' to live in two different, antagonistic cultures without fully belonging to either (Park; Stonequist); this social-psychological type is closely related to;

* involuntary marginality: individuals and groups who for reasons of race, ethnicity, 'sex, 'underdevelopment,' and the like are not able to participate in normative social statuses, roles, and offices and their obligations and duties. They fail to share in both material and nonmaterial resources available to other members at the center of society, and thus who experience themselves as personally alienated (Germani); and

* voluntary marginality: individuals and groups who consciously and by choice live outside the normative statuses, roles, and offices of society because they reject hierarchical social structures, though there will be attempts to perpetuate this spontaneity by social control or in conventicles within the normative social system. Though freely chosen, they will eventually share in some of the same conditions as involuntary marginals (Turner).

The two terms I have chosen, involuntary and voluntar', need to be used with caution. It is important not to transfer the modern, enlightened democratic ideology of 'voluntary associations' and 'freedom of assembly' to Greco-Roman antiquity and thus Christianity. Yet, within certain social restrictions Greco-Roman society had its own sort of volurtary associations: collegia, clubs, trade guilds, burial societies, as well as schools and mystery cults (Danker 1992:501-505). Moreover, within Judaisn there existed a variety of religious sects and parties. Thus, after a further comment about method, I shall also attempt to indicate how one might approach the Gospel of Matthew through these three types of marginality.

\section{TEXTS AND CONTEXTS}

How is the book of Matthew related social realities? How does one move from text to social context? This paper is not the place to develop either a social-historical or social-scientific hermeneutic (see e g, Van Staden 1991). Yet, I would say that there is a dialectical relationship between text and social context: economically/socially/poiitically located ideology generates literature; but literature also challenges economically/socially/politically located ideology 4 .

I still try to discover how the narrative world is related to authorial intention and how text is related to social historical context. One possible metaphor is that Matthew's narrative is not a steamy bathroom mirror that, when wiped with a towel, allows you to see yourself better; rather, it is a foggy window that can be a mirror, but is 
nonetheless a window. By wiping away the fog at the appropriate places, one can see through the text to the author's social-historical context. The keys are the appropriate models and the the appropriate places.

\section{MATTHEW AND MARGINALITY}

\subsection{Normative scheme A: A macrosocial model}

As noted above, according to Germani (1980:50) the first task is to define 'the normative scheme,' that is, the values and norms that define status; the legitimate, expected, or tolerated areas of participation; and the assignment mechanisms of individuals to each category. What is the center from which various persons and groups can be seen to be marginal? What are the missing objective and personal dimensions? This determination is not a simple task because there are competing 'normative schemes' and correspondingly different marginalities in Greco-Roman and Jewish antiquity and the New Testament. As a point of departure for gaining access to one part of the normative scheme, I note first Ritzer's (1983:309) macroscopic-microscopic continuum of social levels.

\section{A simplified macroscopic-microscopic continuum}

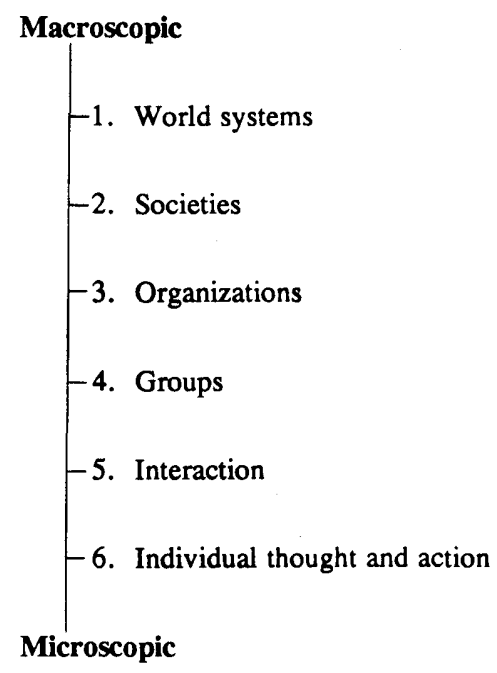


One of the highest macrosocial levels ('societies') for the writings of the New Testament period can be understood through the model of an advanced agrarian society. Several New Testament scholars have employed the model developed by Lenski (1966) and Lenski \& Lenski (1987:164-208) to clarify social stratification in the Roman Empire5. I have also used it (see Duling 1991c, 1992a:99-116; 1992b, 1993). Its main features correspond to what MacMullen (1974) has called 'verticality' in Roman society (cf also Meeks 1983:51-73). Drawing on Alföldy's work and using data from Josephus, archaeology, and the rabbis, Fiensy (1990:158) has adjusted this same model down a level for Palestine. I have added a few speculative percentages from various authors. It looks like model A (see Lenski 1966:243-248; Saldarini 1988:40-45; Fiensy 1990:155-170; Duling \& Perrin 1994:56).

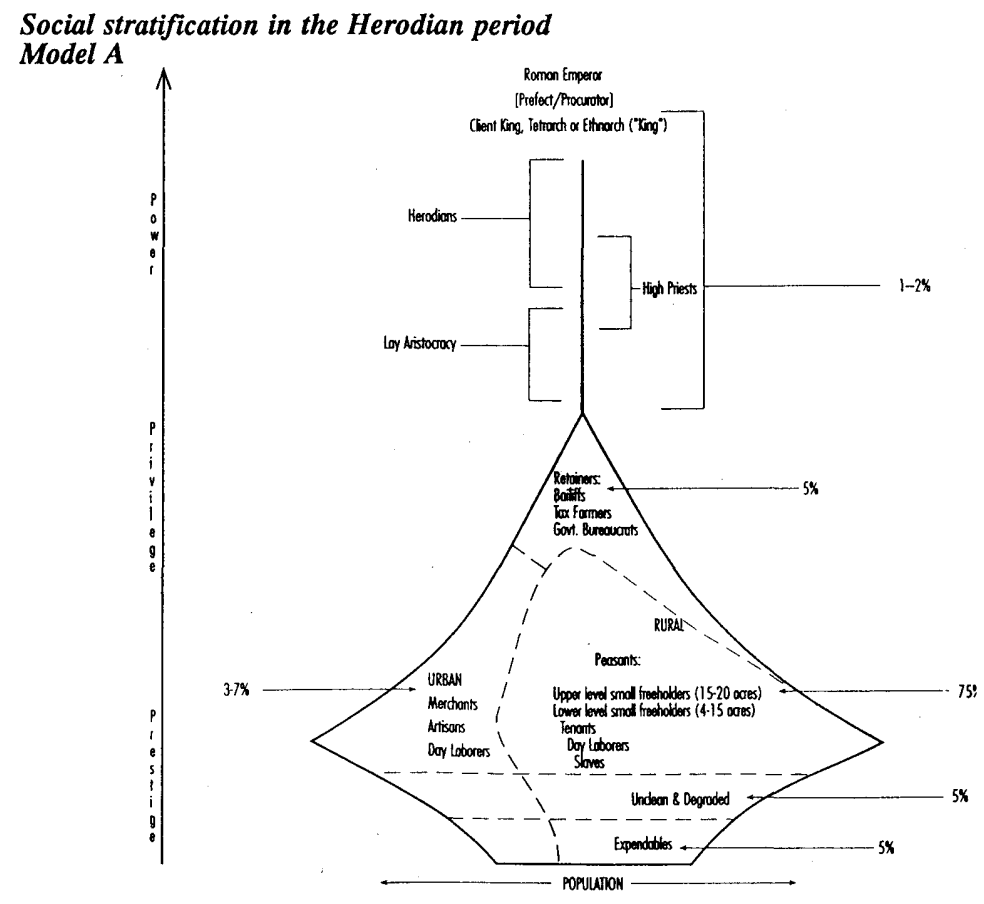

Adapted from D. Fiensy, The Social History of Palestine in the Herodian Period, p. 158, based on G. and J. Lenski, Human Sociefies, p. 203, and G. Alfödy, Die römische Gesellshoft

In this model the primary bases of social stratification - power, privilege, and prestige - are primarily economic and political; kinship and religion are implied - for example, succession among the ruling groups and religious support of the 'state' - but they are less conspicuous. There are a very few at the top of the vertical social structure; 
though this is not indicated, they are urban. The vast majority are at the bottom. There is no real 'middle class'. Indeed, one should think of a status hierarchy rather than 'social classes' based solely on economics 6 . The lower part of the model is divided into urban and rural sections, with rural peasants dominating. The upper strata are virtually all urban (Oakman 1986; Rohrbaugh 1987:103-119). Retainers (mainly bureaucrats), merchants, artisans, fishermen, day laborers, and many expendables belong in or near the towns and cities, while the upper level small freeholders (15-50 acres), lower level small freeholders (4-15 acres), tenant farmers, some day laborers, and most slaves belong in the rural districts. The expendables have new been subdivided into 'unclean and degraded' and 'expendables'. The model implies accepted institutional authority. Clearly it is, in Turner's terms, a 'structure,' in this case a hierarchical structure?

\subsection{Matthew and marginality from the macrosocial perspective: Involuntary marginality}

There are further modifications of the above model that need to be made, all of which have to do with decisions about Matthew and marginality. First, this reconstructed model roughly corresponds to certain dimensions of Palestine at the time of Jesus. It does not correspond quite as well to the usual time for the composition of the Gospel of Matthew itself, circa 80-90 C E.

Thus, the Herodians should be removed and the priests have much declined in political power. Second, some client rulers may have experienced 'psychological' marginality simply because they were Roman colonials ('relative deprivation') ${ }^{8}$; nonetheless, in what follows I shall exclude the upper strata, including Idumeans and Jews (Caesar; rulers of the Gentiles; prefects/procurators; ancestral native kings; Herodian client kings; the high priest Caiaphas; chief priests; elders). Third, for the same reasons, it is probably also best from the perspective of this model to exclude the retainers of the upper strata (toll collectors; Roman centurions; high priest's guards; most priests; most scribes). Fourth, this model operates best for certain forms of economic and political oppression, especially the colonial context of the Eastern Empire, and for rural-urban contrasts, demography (population shifts), and perhaps psychosocial marginality (powerlessness; helplessness; status inferiority). Fifth, other important status criteria (based on other models) need to be considered, especially in relation to Palestinian Judaism, for example, units further down Ritzer's continuum, notably kin groups, regional and ethnic groups (Idumeans; Samaritans; Gentiles in general), religious parties (Essenes), and gender within patriarchal contexts. As an example, toll collectors and scribes would not be considered marginal from the perspective of the above macrosocial model because they were retainers of the ruling classes; yet, toll collectors, while economically and somewhat politically advantaged, were universally despised by native peoples in the Roman Empire (Lewis 1983:156-184; Donahue 1992: 337-338) and scribes were sometimes considered marginal if they belonged to a marginal group, for example Essenes. Sixth, it is not always easy to distinguish 
between 'unclean and degraded' and 'expendable' in the Jewish context. Prostitutes, those with skin diseases, and demoniacs, for example, might fall into both categories. Finally, one might make a case that in a limited good society, especially in the 'colonial' context like Palestine, all peasants - about three-quarters of the population - were marginal. Given that this is a peasant society, I have elected to omit upper level peasants.

With these qualifications, I suggest that from the above macrosocial perspective the lower social strata would have been seen as 'involuntary marginals'. Here is a sample inventory implied in Matthew's gospel ${ }^{9}$ :

1. Forced laborers (implied): $5: 41 ; 27: 32$

2. Day laborers (غ่ $\rho \gamma \alpha \dot{\tau} \eta \varsigma): 20: 1,2,8$; perhaps $9: 37,38 ; 10: 10$

3. Some slaves:

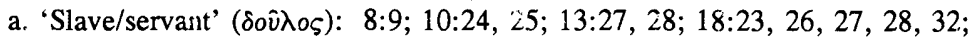
$20: 27 ; 21: 34,35,36 ; 22: 3,4,6,8,10 ; 24: 45,46,48,50 ; 25: 14,19,21$, 23 [twice], 30; 26:51

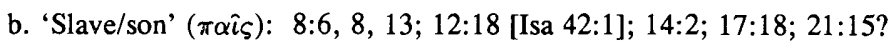

4. Some peasants, urban poor, and destitute:

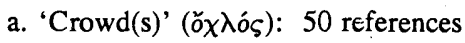

b. 'Tenant farmers' ( $\gamma \varepsilon \omega \rho \gamma o ́ s): 21: 33$

c. 'Poor' ( $\pi \tau \omega \chi o ́ \varsigma): 5: 3 ; 11: 5 ; 19: 21 ; 26: 9,11$

d. Receivers of alms (implied by $\dot{\varepsilon} \lambda \varepsilon r_{,} \mu \circ \sigma u ́ \eta$, 'alms' in $6: 1-6 ; 19: 21$ )

5. Unclean and degraded (dishonored):

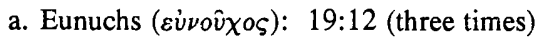

b. Ritually unclean: ([Jesus and] certain disciples): 15:2

c. Leper's $(\lambda \varepsilon \pi o ́ s): 8: 2 ; 10: 8 ; 11: 5 ; 26: 6$

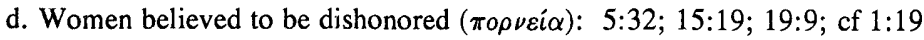

e. Woman with hemorrhage: 9:20-22.

f. Women outside their usual home 'space' (who follow Jesus)

g. Those with 'every disease and every infirmity': 4:23 and 9:35; with 'various diseases and pains': 4:24; 'all who were sick': 8:16; 'their sick': 14:14; 'sick: $14: 35$

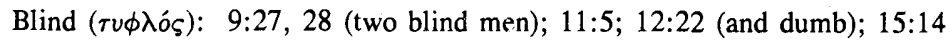
(four times); 15:30;15:31; 20:30 (two blind men); $21: 14$ 
- Lame ( $\chi \omega \lambda o ́ \varsigma): 11: 5 ; 15: 30-31 ; 18: 8 ; 21: 14$

- Deaf ( $\kappa \omega \phi o ́ \varsigma): 11: 5$

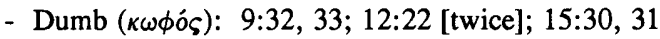

- Deformed ( $\kappa v \lambda \lambda o ́ s): 15: 30,31$

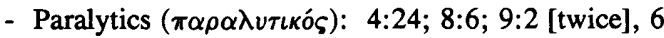

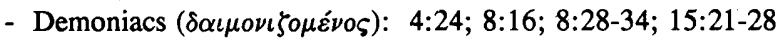

- Epileptics ( $\sigma \varepsilon \lambda \eta \nu \iota \alpha \zeta o \mu \varepsilon ́ \nu \circ \varsigma): 4: 24$

6. Expendables:

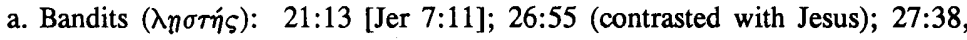
36 (mock Jesus on cross)

b. Prostitutes $(\pi \circ \rho \nu \eta): 21: 31,32$

A few further remarks are in order. Matthew's 'crowds' are undifferentiated. Nonetheless, the writer implies that they contained women and those with all manner of debilitating disease and sickness (Duling 1978:392-410). Perhaps they also contained bandits, eunuchs, slaves, tenant farmers, and other artisans and fishermen. Matthew writes that Jesus had compassion on 'the crowds' who are 'like sheep without a shepherd' (9:36; Duling 1992a:112-113), and the above strata represent the 'lost sheep of the house of Israel' to whom Jesus and the disciples direct their activities (Matt 10:6; 15:24). They do not participate in normative social statuses, roles, and offices, and they fail to share in both material and nonmaterial resources. It could be argued that peasants and village artisans who have lost their ancestral lands ${ }^{10}$, and fishermen whose activities were heavily taxed (Hanson 1991), should be included. Jesus and some of his disciples are from this group. Herders $\left(\pi \circ \mu \mu^{\prime} \nu\right)$ fall within another structure, but they would be marginal, though the term 'shepherds' is used positively as metaphor (9:36; 25:32 [sheep/goats]; 26:31, 'strike the shepherd' [Zch 13:7]). In this context, I would exclude these groups ${ }^{11}$. In any case, whatever decisions are made about center and margin, it is clear that the percentage of involuntary marginals would have been quite high, even omitting some peasants. It is impossible to discuss all the remaining groups and persons in the First Gospel here. Let us take a representative example, 'the poor'. The plural $\pi \tau \omega \chi 0 i$, which in the synoptics in general refers to the destitute (Schottroff \& Stegemann 1986:16; cf also Sobrino 1984; Stegemann 1984; Stegemann \& Schottroff 1984; Malina 1986:148-159; Hanks 1992:414-424), is used clearly as an actual social condition in four verses: $11: 5 ; 19: 21 ; 26: 9,11$, to which one must compare 'poor in spirit' (oi $\pi \tau \omega \chi o \grave{~} \tau \hat{\varphi} \pi \nu \varepsilon \dot{\mu} \mu \alpha \tau \iota$ ) in 5:3. In Matthew 26:9, which simplifies Mark 14:5, the disciples are angered at the woman's 'waste' of an alabaster flask of 'very expensive perfume' (26:7): 'For this perfume might have been sold for much 
[money] ( $\pi \circ \lambda \lambda \circ \hat{v})$ and given to the poor $(\pi \tau \omega \chi 0 \hat{\iota} \varsigma)$ ' (26:9). Jesus' defends the

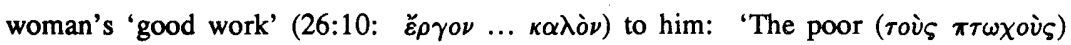
you always have with you, but me you do not always have' (26:11). In this passage, the perpetual presence (and pervasiveness) of the poor is assumed ( $\pi \dot{\alpha} \nu \tau o \tau \varepsilon)$. Yet, the act of one marginal - probably a 'promiscuous' woman who encounters (sits with? ${ }^{12}$ ) Jesus at table - appears to override social concern for other marginals, the poor.

One might conclude from these comments that the 'preferential option for the poor' in Matthew is qualified by the woman's symbolic act preparing Jesus for burial (Mt 26:12-13). There is probably some validity to this conclusion: for Matthew ideology - Christology and eschatology — is paramount. Furthermore, the impression is related to Matthew's apparent tendency to think in terms of the city and wealth, and to his addition of 'in spirit' to 'the poor' in 5:3 (Kingsbury 1978:56-73; Crosby 1988:39$43^{13}$ ). One can conclude that the portrayal of the disciples' irritation is understandable in the light of what has gone before with regard to the young man (Mt 19:16-22; see Mk 10:17-22; Lk 18:18-23). Jesus has told him, 'If you want to be perfect ( $\tau \varepsilon \lambda \varepsilon 10 \varsigma$ ), go, sell your possessions ( $\tau \dot{\alpha} \dot{v} \pi \dot{\alpha} \rho \chi o \nu \tau \alpha)$ and give to the poor ( $\pi \tau \omega \chi 0 \hat{\iota} \varsigma)$, and you will have treasure ( $\theta \eta \sigma \alpha v \rho o ́ \nu)$ in heaven, and come follow me' (19:21). Apparently 'the poor' would have had much to gain for the young man has 'many possessions' (19:22: $\kappa \tau \dot{\eta} \mu \alpha \tau \alpha \pi \circ \lambda \lambda \dot{\alpha})^{14}$. Here, of course, are Matthew's familiar discipleship/following terms, and with them the question of voluntary poverty is articulated: The true disciple is commanded not to store up treasures on earth, but in heaven $(6: 19-21)$.

The third passage is John's question to Jesus and Jesus' answer, reworked from Q (Q 7:18-23; Mt 11:2-5) ${ }^{15}$. Jesus' miracle working in Matthew 11:5 is full of allusions to Isaiah ${ }^{16}$, and 'the poor have good news preached to them' alludes to the famous Jubilee passage in Isaiah 61:1 (1QH 18:14; Lk 4:18). That Isaiah is Matthew's favorite scriptural text suggests that he is quite aware of these scriptural allusions. While the verb $\varepsilon \dot{v} \alpha \gamma \gamma \varepsilon \lambda i \zeta o \mu \alpha \iota$ is a Matthean hapax, its cognate $\varepsilon \dot{v} \alpha \gamma \gamma \varepsilon \lambda \iota \nu$ calls forth the key Matthean summaries $(4: 23 ; 9: 35)$ and, indeed, the central proclamation of the kingdom of Heaven (Duling 1992c:57-58). There is no theme more central than this theme in the gospel. Thus, the Matthean author stresses that the poor hear the good news, but his view on actual poverty is somewhat mixed. It will have to be compared to his ideal of volunatary marginality.

\subsection{Normative schemes B, C, D: Microsocial models}

Another way to understand marginality, that is, the way that values and norms define status in relation to participation, as well as the assignment mechanisms of individuals to each category, is to move further down Ritzer's macroscopic/microscopic continuum to groups (no 4). Groups are also important for involurtary marginality, but they are 
especially significant for voluntary marginality. In Turner's terms, voluntary individuals and groups are those who spontaneously but consciously choose to live outside the normative statuses, roles, and offices of society because they reject hierarchical social structures ('spontaneous communitas'). Nonetheless, says Turner, there will be gradual attempts to perpetuate this spontaneity by social control within the group ("normative communitas') or in conventicles within the normative social system ('ideological communitas').

Ever since Weber's contrast between charisma and routinization, social theorists have persistently contrasted non-structured groups with structured institutions. Victor Turner's contrast between anti-structure and structure and his view that ant structure tends toward structure is only one example. Bruce Malina, building on the work of the Mediterranean network anthropologist Jeremy Boissevain, contrasts 'coalitions' as nonhierarchical structures with 'corporations' as hierarchical structures (see Boissevain 1974:170-205; Malina 1986:13-67; 1988:14). Drawing further on the work of Herbst (1976:18-19, 29-40), Malina (1986:66-67) has also attempted to contrast nonhierarchical groups with hierarchical organizations on the basis of task allocation.

Non-hierarchical groups are best seen with respect to their opposite, hierarchical organization, of which the macrostructure above is but one type.

\section{Hierarchical organization \\ One person - One task}

\section{Assumptions}

1. Organization by decomposing into smaller and smaller units.

2. Each unit or person allocated a single task.

\section{Consequences}

1. A single structure of relationships between units.

2. Uniform type of relationship: units and persons linked by superior subordinate relationship.

3. Every unit and person has one, clearly demarcated, set of functions with sharp boundaries between units and persons.

4. Decisions are made for subordinates by superiors.

5. Principle: decision making is separated from task performance. 


\section{Hierarchical model}

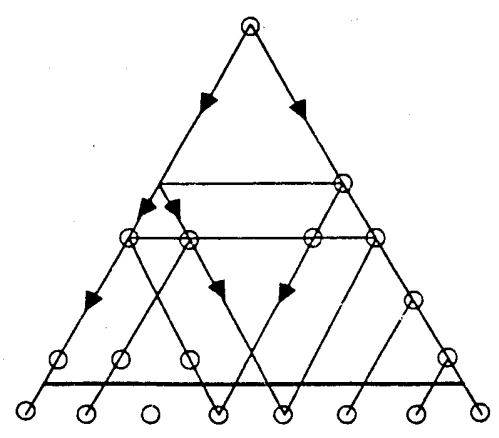

\section{Hierarchical groups}

\section{Characteristics}

1. The capacity for multi-structured functioning.

2. The capacity for achieving and maintaining 'directive correlation' of ongoing activities, that is, the work of each supports and facilitates the work of others in the direction of the achievements of a joint aim.

Models C, D, E: Non-hierarchical groups

\section{GROUP}

\section{Matrix group}

Model $B$

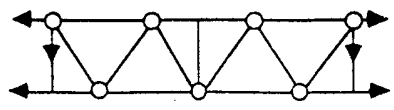

\section{TASK}

Each person has a specialized function, but overlapping competence (two to four tasks each) members work together; no necessary limit to size) 
2. Composite autonomous group Model C

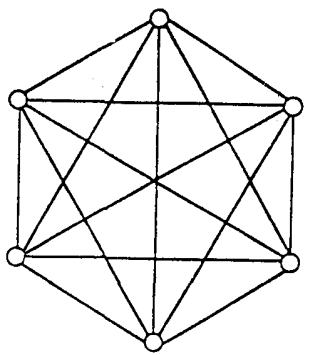

Each person can carry out all tasks (members work together; each person equipotential; no specialized leadership function; no specific, ongoing structure; size relatively small

To Herbst's two non-hierarchical groups, Malina (1986:67), again building Bossevain (1974:170-205), adds a third:

\section{Network group}

Model D
Geographically dispersed individuals or subsets (no direct control)

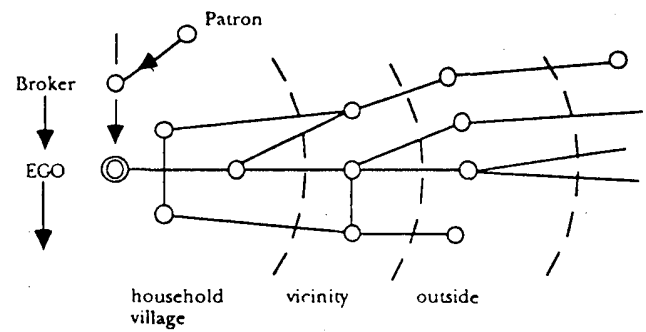

Except for the last, these interesting models are drawn from modern industrial relations. Yet, again, there is a kind of rough correspondence between groups 1, 2 and 3 in reverse order and Turner's three types of non-hierarchical groups:

$$
4
$$

Turner

ideological communitas

normative communitas

spontaneous communitas

\section{Herbst}

matrix group

composite autonomous group

network group 
These non-hierarchical groups can be viewed as illustrations of 'voluntary marginality', though in the case of Herbst's composite autonomous and matrix groups there is some 'industrial engineering'. As the vertical arrow indicates, there is at the group level a gradual tendency toward hierarchy, as Turner realized. Time, size, the need for social control, and increasing division of labor (task allocation) lead toward normative communitas and eventually hierarchy.

\subsection{Matthew and marginality from microsocial perspectives: Voluntary margi- nality}

Where does the Gospel of Matthew belong with respect to voluntary marginality? At the microsocial level, the first gospel reveals several types of groups. There are clear indications of spontaneous sub-groups of the network type from the days of the historical Jesus. The best example is the mission charge in Matthew 10, especially 10:915. This text segment, which has echoes in Didache 11, 12, and 16:3, represents an ideology similar to, though not exactly like, that of the itinerant Cynic philosophers (Downing 1988:47-48; see also the discussions in Schottroff \& Stegemann 1986:160167; Horsley 1988:46-47). The command to take 'no gold' and 'no bag' for food (cf 1 Cor 9:4, 14, 17-18; Didache 11.6), no change of tunic, and no sandals (a sign of wealth) are indications of voluntary poverty. If the 'no bag' is a contrast to itinerant Cynic preachers who carried a bag that symbolized their self-sufficiency, the stress may be less on actual begging than on eating common meals with others ${ }^{17}$. In this regard, the itinerant apostles, wise men, prophets, and scribes of Matthew's Gospel are commanded to carry on the Jesus tradition of a non-hierarchical faction. 'Therefore I send you prophets and wise men and scribes, some of whom you will kill and crucify, and some you will scourge in your synagogues and persecute from town to town ...' (Mt 23:34; italics = Matthean additions). The danger, as in the Didache, is false prophets (Didache 11; Mt 7:15-23). Yet, one would have to modify the network model slightly since the itinerants themselves clearly have some status and authority (see further Theissen 1977).

This is not the only non-hierarchical group in the Gospel of Matthew. I turn now to an 'appropriate passage' that points to a slightly different group, one that may suggest a more settled community. 
[The Pharisees love...] to be called

Rabbi by the people.

do not be called Rabbi

for one is your teacher,

9) And father do not call yourselves (pl.)

for one is your (pl.) father,

10) Neither be called (pl.) tutors,

for your (pl.) tutor is one,
8) But (as for) you (pl.)

but you (pl.) are all brothers.

on earth,

the heavenly.

the Christ.

Viviano (1990:10) represents most current opinion when he says that this passage contains 'a critique of synagogne offices and titles that are merging in and around the rabbinic academy of Jamnia/Yavneh at this time ....' The rejected titles of honor are 'Rabbi', known from Rabbinic references to teachers prior to 135 C E (Lapin 1992: 600-601) and from inscriptions (Cohen 1981:1-17) but used elsewhere in Matthew only by the traitor Judas (Mt 26:25, 49); 'father,' also known from Rabbinic and inscriptional references (Viviano 1990:20; Hengel 1966:145-183; Hachlili 1992:260); and $\kappa \alpha \theta \eta \gamma \eta \tau \dot{\eta}$, which Winter (1991:152-157) has shown to mean 'private tutor' in Greek, though it might represent the Hebrew moreh, as in moreh hazzedek, the 'Teacher of Rigiteousness' (4QpPsa 37 [= 4Q 171] 3:15-16; 1QpHab 2:8; CD 1:9-11; Viviano 1990:11). Viviano notes four 'run-ons' placed at the right on the above chart. I would add that since the heavenly/earthly contrast and the Christ are Matthean redactional emphases, so probably is the designation for members of Matthew's group, 'brothers'. This is the language of 'fictive-' or 'pseudo-kinship' (see Pitt-Rivers 1968:408-413). Though 'crowds' are mentioned (23:1), clearly the intended recipients are 'disciples' - in other words, the Matthean brotherhood - and this points to the recipients of the gospel as a 'brotherhood' (cf also 5:21-26; 7:1-15; 12:46-50; 18:15-22; Duling 1995). This 'brotherhood' has an 'egalitarian' ideology. Pharisaic titles of status in relation to the central activity of teachers and those taught are rejected by the author of Matthew for the 'brotherhood'.

The ideology of this passage represents a version of Turner's non-hierarchical group, an ideological communitas. It also represents Boissevain's and Malina's 'faction' and Herbst's 'composite autonomous group'. Each person can carry out all tasks; each person is equipotential; members work together; there is no specialized leadership function, and no specific, ongoing structure. One could develop this contrast of antistructure and structure much further. 
It should be emphasized again that Matthew's 'network' and 'composite autonomous' orientations represent an ideological communitas. However, as Turner was aware, there are pressures toward hierarchy. Thus, despite this Matthean ideology, there appear to be in the Matthew group those who are more equal than others (Duling 1992b; see Stanton 1994). In the first place, there are undefined central persons with scribe-related labels and functions:

1. 'Apostles' (10:2).

2. 'Prophets' $(5: 10-12 ; 11: 9 ; 10: 40-42 ; 13: 57 ; 21: 11,23-27 ; 23: 29-36$; all of the formula quotations, including Psalm 78:2 and 110:1, are from 'prophets').

3. 'Teachers' $(5: 19 ; 28: 20)$.

4. 'Scribes' (13:52; 23:34).

5. 'Righteous men' (10:41-42).

6. 'Wise men' (23:34).

Moreover, the ascription of honor to Peter (lower status) by Jesus (higher status) implies a transfer of authority (16:17-19; Duling 1987a:21). Thus, like its rivals, the Pharisees, the Matthew group is not simply a non-hierarchical communitas, but is on its way toward a hierarchical structure (normative communitas). I have elsewhere attempted to represent this movement as a so-called 'leaderless group' (Duling 1987b; see also Fisher \& Ellis 1990).

In short, the above models illuminate several types of groups related to marginality in the Matthean gospel. One example of what Turner calls spontaneous marginality would be the ideology of a group of the network type from the days of the historical Jesus (e g, 10:5-15, 40-42; 23:34). Another would be the ideology of 'leaderless group', or at least the group without titles of honor (23:8-10). This would be Boissevain's and Malina's 'faction' and Herbst's 'composite autonomous group'. Nonetheless, in my view there is also a clear tendency toward structure, or what Turner calls normative marginality.

From this perspective, I return to the example of 'the poor'. The macrosocial model of an agrarian society offers a lens through which to view statements about those who are involuntarily marginally poor in the First Gospel. Microsocial groups offer a lens through which to see the ideal of voluntary poverty. The mission statements that fit the network model are commands to perpetuate the ideal of voluntary poverty (e g, $10: 5-15,40-42 ; 23: 34)$. A similar ideology occurs in the story of the young man: he cannot 'follow' because he cannot give up his 'many possessions'. Many other examples could be cited, not least of which is the passage that Donahue claims is the 
hermeneutical key to the gospel, the 'parable' of the Sheep and the Goats in Matthew 25:31-46. On the one hand, the language reflects the ideal of voluntary poverty; on the other, the ideal reflects actual poverty: 'Truly I say to you, as you did it to one of the least of these my brothers (and sisters), you did it to me' $(25: 40,45)$. At the same time, those critics who sense a step back from the ideal perceive the move toward 'normative marginality': 'For the poor you always have with you, but me you do not always have'. Indeed, perhaps here we have the clue to Matthew's 'Blessed are the poor in spirit, for theirs is the kingdom of heaven' (Mt 5:3).

\section{THE AUTHOR OF MATTHEW AS 'MARGINAL MAN'}

If we once again define a 'Marginal Man' as an individual who, because of birth, migration, conquest, and the like is 'doomed' to live in two different, antagonistic cultures without fully belonging to either, how does Matthew look? Here I shall only out line a proposal.

* The author of the gospel is a scribe (13:52). There are a several current studies on writing and writers in antiquity (Lemaire 1992:999-1008) and some of them have to do with the Gospel of Matthew (Saldarini 1988; Orton 1989; Wire 1991:87-121; Yaghjian 1992). Current estimates of the number of those who could write in antiquity are quite low. From the perspective of macrosocial stratification, the author of Matthew ranks at least as a retainer of the elite strata. Moreover, he has much honor from the perspective of scribalism in traditional Judaism. Yet, he is concerned about those from the lower strata and represents a tradition infused with involuntary marginality, and so stands between two cultures.

* The scribe's opponents are Pharisees, a rival faction within Judaism. Yet, for the gospel writer, Pharisaism is becoming 'normative', that is, the center; again, he is between two cultures.

* The Matthean author 'brings out of his treasure what is new and what is old' (13:52), a dominant theme in the gospel concerned especially with the Torah and its interpretation (e g, 5:17-48). He stands between the old and the new.

* The first two chapters suggest that Matthew knew conventional forms of the encomium of the progymnasmata (Neyrey 1990), as the modified bios form suggests. Yet, his use of the formula quotations and his stress on interpreting and making a hedge around the Torah $(5: 17-6: 48)$ point to the Pharisaic scribalism. 
His 'synagogue Greek' is derived in part from the Septuagint; yet, he uses Christian sources: Mark and Q. He improves Markan syntax, yet his language is Semitizing (Luz 1990:49-76). Matthew seems to stand on the boundary of Greek and Jewish education.

* Matthew's has concern for the 'lost sheep of the house of Israel' $(10: 6 ; 15: 24)$, but ultimately the mission is to the Gentiles (28:16-20). Presumably his concerns are divided.

* Is the author of Matthew a Jewish Christian or a Christian Jew (Overman 1990)? Would he have understood this question? If he did, he realized he stood between two 'cultures'.

\section{CONCLUSION}

In this paper, I have attempted to clarify several dimensions of the concept 'marginality'. I have also attempted to relate the Gospel of Matthew to these various dimensions of the term. The author of the Gospel of Matthew has an ideology of 'voluntary marginality', but his gospel includes some hope for 'involuntary marginals' in the real world, though it is tempered. On the basis of several multiple criteria he might be called a 'Marginal Man'. That will be a subject for further investigation.

\section{ENDNOTES}

* This essay is a reworked version of the paper originally published in SBL Seminar Papers (1993), Atlanta-Scholars Press, pp 642-671. HTS is granted permission to reprint the article.

1 While marginal, they are examples of faith and initiative.

2 Competing 'normative schemes' sounds like competing 'plausibility structures' from the perspective of sociology of knowledge (Berger \& Luckman 1966:154-163).

3 One hears the echo of Max Weber's 'charisma' and 'routinization' here; indeed, Turner (1969:133) mentions Weber (1968) in this context.

4 From the perspective of Marxist literary criticism, literature as art is part of an ideological consciousness related to a superstructure that is determined by the economic base or infrastructure. Yet, literature is not the mere passive, unconscious reflection of economics. Schematically, the relation is not simply productive forces $\longrightarrow>$ social relations $\longrightarrow>$ ideology $\longrightarrow$ text. This would be so-called 'vulgar Marxism'. Thus, art can also challenge the ideology of which it 
is a part, and thus the social, political, and economic order that undergirds it. Art is an expression of ideology, but it also distances itself from ideology (see Eagleton 1976). On ideology, see McLellan (1986) and Larrain (1992 [1979]).

5 Some scholars who have used the Lenski model are Elliott (1986:1-33), Waetjen (1989:6), Fiensy (1990:155-176), Saidarini (1988:20-27) and Rohrbaugh (1993).

6 Explicit descriptions of class are rare and limited to Rome (see Meeks 1983:53-55; Rohrbaugh 1987:103-119).

7 I have also added to the model what the Lenski's call a 'specialized society' still present in Palestine, namely, the semi-nomadic herders. They represent a different, parallel social system altogether.

8 One need only recall that Eleazar, son of Ananias the High Priest and governor of the Temple, was instrumental in the revolt against Rome (Josephus, Wars 2.17.2 \#409; see also Aberle 1970:209-14; Gager 1975:27-28).

9 For a fuller, but slightly different arrangement, see Duling (1992:102-103).

10 For this reason, some analysts claim that village artisans, despite some economic success, are beluw the peasants.

11 In this model peasants represent the majority; for the debate abrut whether one can speak of marginality in traditionally structured societies where those of lower social status see thamselves as elites see them, for example, in caste systems, see Germani (1980:52): 'In such a society the very concept of marginality does not emerge as a social perception scheme'.

12 Corley (1992:208; see also Anderson 1983:3-27) concludes:

Matthew, the gospel considered the most androcentric of all the Synoptics, is the only gospel which portrays women reclining with men for meals. Only in Matthew are women allowed an equal place at the table .... Furthermore, Matthew allows for the presence of women identified as 'courtesans' among the followers of Jesus [Matt 21:31-32]. 'Sinners,' a group which in Matthew includes women, join Jesus and his disciples for meals [9:9-13] .... In spite of the larger controversy over the 'public' behavior of Greco-Roman women 
[that is, in some circles, they reclined at table with men, while others continued to think of such practices as dishonorable], Matthew boldly affirms the presence of women accused of promiscuity among the followers of Jesus.

13 Crosby (1988:154-55) argues that Matthew does not 'canonize' poverty, but neither does he 'spiritualize' it.

14 For the view that what is implied is the redistribution of wealth in a limited good society, see Malina (1986c:155-156).

15 It is generally accepted that ta erga tou Christou in Mt 11:2 refers back to Jesus' miracles in Mt 8-9 (cf Duling 1978:392-410). Davies \& Dale (1991:240) argue that it also refers to Matthew 5-7 because of 11:5f, 'the poor have good news preached to them' in relation to $4: 23-26$. In the light of 5:16 ('see your kala erga') and 11:20 (hai pleistai dynameis), this conclusion seems to stretch the meaning of ta erga in Matthew 11:5.

16 Isaiah $26: 19 ; 29: 18 ; 35: 5-6 ; 42: 7,18 ; 61: 1$. Matthew adds 'lepers', apparently in accord with Matthew 8:1-4.

17 Crossan has called this phenomenon 'unbrokered egalitarian commensality'. Drawing on Scott (1977:225-26), he states:

... peasant culture and religion is actually an anticulture, qualifying alike both the religious and political elites that oppress it. It is, in fact, a reflexive and reactive inversion of the pattern of exploitation common to the peasantry as such. 'The radical vision to which I refer', he [Scott] continues, 'is strikingly uniform despite the enormous variations in peasant cultures and the differing great traditions of which they partake .... At the risk of overgeneralizing, it is possible to describe some common features of the reflexive symbolism. It nearly always implies a society of brotherhood in which there will be no rich and poor, in which no distinctions of rank and status (save those between believers and non-believers) will exist. Where religious institutions are experience as justifying inequalities, the abolition of rank and status may well include the elimination of religious hierarchy in favor of communities of equal believers. Property is typically, though not always, to be held in common and shared. All unjust claims to taxes, rents, and tribute are to be nullified. The envisioned utopia may also include a self-yielding 
and abundant nature as well as a radically transformed human nature in which greed, envy, and hatred will disappear. While the earthly utopia is thus an anticipation of the future, it often harks back to a mythic Eden from which mankind has fallen away'.

(Crossan 1991b:263-264)

\section{Works consulted}

Aberle, D 1962. A note on relative deprivation theory as applied to millenarian and other cult movements, in Thrupp, S (ed), Millennial dreams in action: Studies in revolutionary religious movements, 209-214. New York: Books.

Alföldy, G 1986. Die römische Gesellschaft. Wiesbaden: Steiner.

Anderson, J C 1983. Matthew: Gender and reading. Semeia 28, 3-27.

Balch, D L (ed) 1991. Social history of the Matthean community: Cross-disciplinary approaches. Minneapolis: Fortress Press.

Bauer, D R 1988. The structure of Matthew's gospel: A study in literary design. Sheffield: Almond. (JSNT Suppl 31. Bible and Literature Series 15.)

Berger, P L \& Luckmann, T. The social construction of reality. Garden City, NY: Doubleday \& Company, Inc.

Boissevain, J 1974. Friends of friends: Networks, manipulators, and coalitions. New York: St Martin's Press.

Cohen, S J D 1981. Epigraphical Rabbis. JQR 72, 1-17.

Cooper, J M 1941. Temporal sequence and the marginal cultures. Washington: The Catholic University of America.

Cope, O L 1976. Matthew: A scribe trained for the kingdom of heaven. Washington: The Catholic Biblical Association of America.

Court, J M 1985. Right and left: The implications for Matthew 25:31-46. NTS 31, 223-233.

Crosby, M H 1988. House of disciples: Church, economics, and justice in Matthew. Maryknoll: Orbis Books.

Crossan, J D 1991a. Open healing and open eating: Jesus as a Jewish Cynic?' Biblical Research 36, 6-18.

1991b. The historical Jesus: The life of a Mediterranean Jewish peasant. San Francisco: Harper Collins.

Dahrendorf, $\mathbf{R}$ 1959. Class and class conflict in industrial society. Stanford: Stanford University Press.

Danker, F 1992. Associations, clubs, thiasoi. $A B D$ 1, 501-503.

Derrett, J D M 1981. Mt 23,8-10: A midrash on Is 54,13 and Jer 31,33-34. Biblica $62,372-386$. 
Donahue, J R 1986. The parable of the sheep and the goats: A challenge to Christian ethics. Theological Studies 47, 3-31.

- 1988. The gospel in parable. Philadelphia: Fortress Press.

1992. Tax collector. ABD 6, 337-338.

Donaldson, J 1973. The title Rabbi in the gospels: Some reflections on the evidence of the gospels. JQR 63, 287-291.

Duling, D C 1978. The therapeutic son of David in Matthew's gospel. NTS 24,392410.

1983. Matthew and the problem of authority: Some preliminary observations. Eastern Great Lakes Biblical Society Proceedings 3, 59-68.

1985. Insights from sociology for New Testament christology: A test case, in Richards, K H (ed), SBL Seminar Papers 1985, 351-368. Atlanta: Scholars Press.

1987a. binding and loosing (Matthew 16:19; Matthew 18:18; John 20:23). Forum 3/4, 3-31.

1987b. Response to E Krentz's 'Community and character': Matthew's vision of the church. Unpublished paper circulated at the SBL Matthew Section.

- 1991a. Book review: Horsley (1989). BTB 21, 123-124.

- 1991b. Matthew's infancy in social science perspective. Unpublished paper discussed at the Context Group.

1992a. Matthew's plurisignificant 'Son of David' in social science perspective: Kinship, kingship, magic, and miracle. BTB 22/3, 99-116.

- 1992b. Egalitarian ideology, leadership, and factional conflict in the Matthean gospel. Unpublished paper delivered in the Gospels Section, SBL, San Francisco, November 1992.

1992c. Kingdom of God, Kingdom of heaven (New Testament and early Christian literature). $A B D$ 4, 56-69.

- 1992d. Matthew (disciple). $A B D$ 4, 618-622.

- 1993. Introduction and annotations on the gospel according to Matthew in the Harper Collins study edition of the New Revised Standard Version.

- 1995. The matthean brotherhood, in Esler P, (ed), Modeling early Christianity: Social-scientific studies of the New Testament in its social context. London, New York: Routledge.

Duling, D C, and Perrin, N 1994. The New Testament: An introduction. New York: Harcourt Brace \& Company.

Eagleton, T 1976. Marxism and literary criticism. Berkeley: University of California Press. 
Elliott, J H 1986. Social-scientific criticism of the New Testament: More on methods and models. Semeia 35, 1-33.

1990. A home for the homeless: A social-scientific criticism of 1 Peter, its situation and strategy. 2nd ed. Minneapolis: Augsburg-Fortress.

Fiensy, D 1990. The land is mine: The social history of Palestine in the Herodian period. New York: The Edwin Mellen Press.

Filson, F V 1956. Broken patterns in the Gospel of Matthew. JBL 75, 227-231.

Fisher, B A \& Ellis, D G 1990. Small group decision making: Communication and the group process. 3rd ed. New York: McGraw-Hill.

Gager, J 1975. Kingdom and community: The social world of early Christianity. Englewood Cliffs: Prentice-Hall.

Garland, D E 1979. The intention of Matthew 23. Leiden: E J Brill.

Germani, G 1980. Marginaiity. New Brunswick: Transaction Books.

Green, H B 1968. The structure of St Matthew's gospel. Studia Evangelica 4, 47-59.

Hachlili, $\mathrm{R}$ 1992. Synagogue (diaspora synagogues). $A B D$ 6, 260-263.

Haenchen, E 1951. Matthäus 23. ZTK 48, 38-63.

Hanks, T D 1992. Poor, poverty (New Testament). ABD 5, 414-424.

Hanson, K C 1991. Fishing. Unpublished paper of the Context Group.

Hengel, M 1966. Die Synagogeninschrift von Stobi. ZNW 57, 145-83.

Herbst, P G 1976. Alternatives to hierarchies. Leiden: Martinus Nijhoff Social Sciences Division.

Hill, D 1965. DIKAIOI as a quasi-technical term. NTS 11, 296-302.

Horsley, R A 1989. Sociology of the Jesus movement. New York: Crossroad.

Karris, R J 1990. Jesus and the marginalized in John's gospel. Collegeville: Liturgical Press.

Kingsbury, J D 1988. Matthew: Structure, christology, kingdom. Minneapolis: Fortress Press.

1978. The verb akolouthein ('to follow') as an index of Matthew's view of his community. $J B L 97,56-73$.

Kloppenborg, J S 1986. Blessing and marginality: The 'persecution beatitude' in Q, Thomas, and early Christianity. Forum 2/3, 36-56.

Lapin, H 1992. Rabbi. $A D B$ 5, 600-601.

Larrain, J A 1992. The concept of ideology. Brookfield: Gregg Revivals.

Lemaire, A 1992. Writing and writing materials. $A B D$ 6, 999-1008.

Lenski, G and Lenski, J 1987. Human societies: An introduction to macrosociology. 5th ed. New York: McGraw-Hill.

Lewis, N 1983. Life in Egypt under Roman rule. Oxford: Clarendon Press.

Luz, U 1989. Matthew 1-7: A commentary. Translated by W C Linss. Minneapolis: Augsburg. 
MacMullen, $\mathrm{R}$ 1974. Roman social relations: 50 B C to A D 284. New Haven: Yale University Press.

Malina, B J 1981. The New Testament world: Insights from cultural anthropology. Atlanta: John Knox.

- 1986a. Christians origins and cultural anthropology: Practical models for Biblical interpretation. Atlanta: John Knox.

1986b. Normative dissonance and Christian origins. Semeia 35, 35-59.

- 1986c. Interpreting the Bible with anthropology: The case of the poor and the rich. Listening 21, 148-159.

1988a. Patron and client: The analogy behind synoptic theology. Forum 4/1, 2-32.

1988b. A conflict approach to Mark 7. Forum 4/3, 3-30.

Malina, B J \& Neyrey, J H 1988. Calling Jesus names: The social value of labels in Matthew. Sonoma: Polebridge Press.

McLellan, D 1986. Ideology. Milton Keynes: Open University Press.

McNutt, P 1993. The Kenites, the Midianites, and the Rechabites as marginal mediators in ancient Israelite tradition. Unpublished paper discussed at the Eastern Great Lakes Biblical Society, April.

Meeks, W A 1983. The first urban Christians: The social world of the apostle Paul. New Haven: Yale University Press.

Meier, J P 1991. A marginal Jew: Rethinking the historical Jesus. 2 vols. New York: Doubleday.

Neyrey, J H 1990. Encomium, progymnasmata and description of first century persons: Josephus' Vita as a test case. Unpublished paper given at the Social science and New Testament interpretation Section, SBL, New Orleans, 1990.

Oakman, D E 1986. Jesus and the economic questions of his day. Lewiston: The Edwin Mellen Press. (SBEC 8.)

Orton, D E 1989. The understanding scribe: Matthew and the apocalyptic ideal. Sheffield: JSOT Press. (JSNT Suppl 25.)

Overman, A 1990. Matthew's gospel and formative Judaism: The social world of the Matthean community. Minneapolis: Fortress Press.

Park, R E 1928. Human migration and the Marginal Man. American Journal of Sociology 33, 881-93.

1931. Personality and cultural conflict. American Sociological Society 25, 95-110.

Pitt-Rivers, J 1968. Pseudo-kinship. International Encyclopedia of the Social Sciences, 8.408-413. 
Ringe, S H 1985. A gentile woman's story, in Russell, L M (ed), Feminist interpretation of the Bible, 65-72. Philadelphia: Fortress Press.

Ritzer, G 1983. Contemporary sociological theory. New York: Alfred Knopf.

Rohrbaugh, R 1987. 'Social location of thought' as a heuristic construction in New Testament study. JSNT 30, 103-119.

1993. Social location of the Markan audience. BTB. (Forthcoming.)

Saldarini, A J 1988. Pharisees, scribes, and Sadducees in Palestinian society: A sociological approach. Wilmington: Michael Glazier.

Schermerhorn, R A 1964. Marginal Man. Dictionary of the Social Sciences, 406407. New York: The Free Press.

Schottroff, L \& Stegemann, W 1986. Jesus and the hope of the poor. Transl by M J O'Connell. Maryknoll: Orbis Books.

Schüssler Fiorenza, E 1983. In memory of her: A feminist theological reconstruction of Christian origins. New York: Crossroad.

Scott, J C 1977. Protest and profanation: Agrarian revolt and the Little Tradition. Theory and Society 4, 1-38, 211-246.

Stanton, G N 1994. Revisiting Matthew's communites. SBL Seminar Papers, 9-23. Atlanta: Scholars Press.

Stegemann, W 1984a. The gospel and the poor. Tr by D Elliott. Philadelphia: Fortress Press.

Stegemann, W \& Schottroff, L (eds) 1984. God of the lowly: Socio-historical interpretations of the Bible. Maryknoll: Orbis.

Stonequist, E V 1937. The Marginal Man. New York: Charles Scribner's Sons.

Theissen, G 1977. Sociology of early Palestinian Christianity. Transl by J Bowden. Philadelphia: Fortress Press.

Thiemann, R F 1987. The unnamed woman at Bethany. Theology Today 44, 179188.

Turner, V 1969. The ritual process: Structure and anti-structure. Chicago: Aldine Publishing Co.

1974. Dramas, fields, and metaphors: Symbolic action in human society. Ithaca: Cornell University Press.

Van Aarde, A G 1994. God-with-us: The dominant perspective in Matthew's story, and other essays. Pretoria: University of Pretoria. (HTS Suppl 5.)

Via, D O 1987. Ethical responsibility and human wholeness in Matthew 25:31-46. HTR 89, 79-100.

Viviano, B V 1990. Social world and community leadership: The case of Matthew 23:1-12, 34. JSNT 39, 3-21.

Waetjen, H C 1989. A reordering of power: A socio-political reading of Mark's gospel. Minneapolis: Fortress Press. 
Weber, M 1968. Economy and society: An outline of interpretive sociology. New York: Bedminister Press.

White, L J 1986. Grid and group in Matthew's community: The Righteousness/honor code in the Sermon. Semeia 35, 61-88.

Wilson, B 1973. Magic and the millennium. London: Heinemann.

Winter, B 1991. The Messiah as the tutor: The meaning of kathegetēs in Matthew 23:10. Tyndale Bulletin 42/1, 152-157.

Wire, A 1991. Gender roles in a scribal community, in Balch 1991:87-121.

Wolf, E 1966 Peasants. Englewood Cliffs, NJ: Prentice-Hall.

Yaghjian, L 1992. How shall we read? A preface to Matthew's protocols of reading, Unpublish Context Group paper. 